\title{
Publisher Correction: Self-association of MreC as a regulatory signal in bacterial cell wall elongation
}

\author{
Alexandre Martins, Carlos Contreras-Martel D, Manon Janet-Maitre, Mayara M. Miyachiro, \\ Leandro F. Estrozi (1), Daniel Maragno Trindade (1), Caíque C. Malospirito, Fernanda Rodrigues-Costa, \\ Lionel Imbert, Viviana Job, Guy Schoehn (1), Ina Attrée \& Andréa Dessen (1)
}

Correction to: Nature Communications https://doi.org/10.1038/s41467-021-22957-9, published online 20 May 2021.

In this article the caption to Fig 4 was inadvertently omitted. The original article has been corrected.

Published online: 11 January 2022

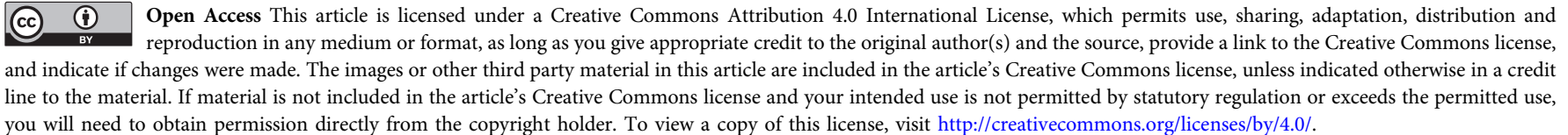

(C) The Author(s) 2022 